\title{
Flavour Improvement of Protein Hydrolysates Derived from Cephalopods Byproducts Using Maillard Reaction: A Short Review
}

\author{
Ayu Shazwani Zulkipli ${ }^{1}$ and Rabeta Mohd Salleh ${ }^{*}$ \\ ${ }^{1}$ Food Technology Division, School of Industrial Technology, Universiti Sains Malaysia, Penang, 11800, Malaysia
}

\begin{abstract}
The conversion of low-value byproducts to high value-added protein hydrolysates by enzymatic hydrolysis is among the top trends in the food industry. Protein hydrolysates provide an opportunity for effective utilization and are considered promising functional food ingredients. However, hydrolyzing effect contributes to taste and aroma defects such as fishy off-flavour and bitterness that impeded their application. Several procedures such as encapsulation, enzymatic hydrolysis with exopeptidase and plastein reaction and Maillard reaction have been compared to mask the undesirable flavour of protein hydrolysates. Maillard reaction has more potential to overcome these challenges and enhance the organoleptic properties of protein hydrolysates. All literature were accessed through available electronic databases. The revised overview can be helpful to explore the rational use of Maillard Reaction with reduced adverse effects. The reaction of Maillard-induced modification on bioactive properties of protein-derived peptides is well-positioned the beneficial effect and facilitate design to obtain applicable functional ingredients for food formulation.
\end{abstract}

Keywords: protein; hydrolysates; cephalopods; Maillard reaction products; bitterness

\section{INTRODUCTION}

Cephalopods are a vital economic resource of global fisheries representing squid, cuttlefish, and octopus (Kechaou et al., 2015). In Malaysia, 70 to 80 thousand tons of cephalopods are annually captured (Food and Agriculture Organization (FAO), 2019). Indian squid and cuttlefish are the primary sources available in Malaysia and are recognized as a local fishery for domestic consumption and economic value (Rubaie et al., 2012). Apart from rich in a nutritious compound, cephalopods are consumed for their delicacy. Hence, the increased exploitation of squid contributes to a considerable amount of byproducts for up to $60 \%$ of the whole weight, defined as leftover after processing (EzquerraBrauer \& Aubourg, 2019). Instead, improving the utilization of protein resources from marine shellfish has become a research hotspot nowadays.

Enzymatic hydrolysis is an effective way to utilize this waste and improve the functional properties of the original protein without reducing its nutritional value (Gbogouri et al., 2004).
In particular, protein hydrolysates and fish protein hydrolysates (FPH) may have a wide variety of purposes in the food sector, including ingredients in formulated food, functional ingredients, nutritional additives and flavouring agent (Kouakou et al., 2014). A growing number of studies have demonstrated FPH is possessed several properties such as solubility, foaming and emulsifying, which offer versatile applications in food ingredients (Gajanan et al., 2016; Ayu Shazwani Zulkipli \& Rabeta Mohd Salleh, 2020). Besides, FPH has been noted to exhibit various physiological functions, such as antihypertensive, antioxidant, antidiabetic, antimicrobial, immunomodulating, and antiosteoporotic effects (Fu et al., 2019).

Nevertheless, protein hydrolysates mainly derived from seafood are often accompanied by undesirable fishy and bitter off-flavour (Normah \& Nur Fazlika Nashrah, 2013; Kouakou et al., 2014). The acceptance of fish protein hydrolysates has been precluded due to the issues of fishy offflavours (Normah \& Noorasma, 2018). The prevalent fish 
flavour is associated with rancid odour and/or flavour, affecting consumer acceptance and limit further application. Besides, the bitterness of protein hydrolysates is correlated with the presence of bitter peptides composed of hydrophobic amino acids (Fu et al., 2019). The hydrophobicity of peptides, peptide length, amino acid sequence and spatial structure also develops bitter taste perception (Kim \& Li- Chan, 2006). Food taste is a crucial criterion that influences consumer acceptability, and it is significant to enhance the overall flavour of protein hydrolysates as food ingredients (Clemente, 2000)

Several efforts have been made to reduce or mask this undesirable flavour, such as encapsulation, plastein reaction, and exopeptidases treatment, followed by Maillard reaction. However, these methods are challenging and possibly do not fully eliminate the bitterness (Idowu \& Benjakul, 2019). Although different ways have been implemented, each of them has limitations. Yet, the Maillard reaction modification seems to be an effective method (Nie et al., 2017; Wang et al., 2015). Hence, this review aims to provide some updated information on the Maillard reaction improving the organoleptic properties and briefly compare it with other methods.

\section{ENCAPSULATION}

Several encapsulation methods have been developed to encapsulate protein hydrolysate proteins, such as spray drying, spray cooling, coacervation and liposomes (Fu et al., 2019). Spray drying has been commonly used to trap peptides in protein and polysaccharide-based carriers due to relatively low production costs and good stability of end products. Nevertheless, high temperatures used during spray drying can trigger the denaturation of protein carriers and modify the peptide structure due to the Maillard reaction, where reducing sugar is present in the system (Mohan et al., 2015). Meanwhile, liposomes are amphipathic colloidal vesicles consisting of hydrophilic, lipophilic, and amphiphilic areas suitable for peptide entrapment. Liposome encapsulation carrier is more capable of achieving higher encapsulation capacity (Allen \& Cullis, 2013). The chitosan-coated liposome method utilizing the milk fat globule membrane has been established to encapsulate Atlantic salmon protein hydrolysates with a strong EE of approximately 71.3\% (Li et al., 2015). However, research remains to be further investigated on the consequence of encapsulation on the bioactivity and bioavailability of peptides in vivo (Li Chen \& Cheung, 2010).

\section{PLASTEIN REACTION}

Plastein reaction refers to a protease-catalyzed response correlated with plastein formation. A plastic gel-like, insoluble and protein-like material is produced from peptide mixtures when a high concentration of protein hydrolysates/peptides are incubated with certain proteases under suitable conditions named as 'plastein' (Idowu \& Benjakul, 2019). Plastein reactions are an efficient method for minimizing the bitterness without losing structure and functionality of protein hydrolysates. The response with glutamic acid diethyl ester resulted in a decreased percentage of hydrophobic amino acids, which enhanced the final products' flavour (Synowiecki et al., 1996). Pepsin-treated soy protein hydrolysates are displayed reduced in bitterness, which indicated the bitter dipeptides (GL and LF) played the leading role in developing plastein chains by condensation (Fujimaki et al., 1970). The rising studies demonstrated the plastein reaction had improved the bioactivity of peptides. However, plastein formation during transpeptidation and condensation requires excessive use of enzymes during the process, lead to an altered peptide series and affected the bioactivity (Udenigwe \& Rajendran, 2016).

\section{EXOPEPTIDASE TREATMENT}

Exopeptidases may selectively cleave terminal peptides and release free amino acids from bitter peptides. Depending on the amino acid of the $\mathrm{N}$-or C-terminal, it is further identified as either aminopeptidase or carboxypeptidase (Raksakulthai \& Haard, 2003). Exopeptidases have been reported to improve the protein hydrolysate flavour derived from animal byproducts (Fu et al., 2018b). The simultaneous use of endoand exopeptidase can ensure effective hydrolysis and selective cleavage of hydrophobic amino acids. As a result, the protein hydrolysates tend to exhibit less bitterness and sustain the amino acid composition. The use of the additional exopeptidases may allow in amino acid residues cleavage pertinent to peptides with bioactive potential, leading to a 
change in bioactivity and functional properties (Cheung et al., 2015). Controlled enzymatic debittering using various forms of exopeptidases are a commonly used and economical process. However, this method has to be optimized for each application to eradicate bitterness. In addition, exopeptidases may further cleave terminal amino acids of peptides, resulting in bioactivity changes (Fu et al., 2019).

\section{THE MAILLARD REACTION}

The Maillard reaction is well-known as a non-enzymatic browning pathway between carbonyl groups of reducing sugars and amino groups from amino acids, peptides, or proteins (Normah \& Noorasma, 2018). Maillard reaction products (MRPs) are naturally formed in food during heat treatment by reducing sugars. Available amino acids can interact with each other, thus modifying the significant food properties such as colour, flavour, and stability (Luo et al., 2014). Furthermore, the pathway and mechanisms underlying the Maillard reaction are among the most complex systems and produce many intermediate products besides melanoidins, such as aldehydes, ketones, and heterocyclic compounds (Jiang et al., 2018). Nevertheless, the Maillard reaction is notoriously difficult to control. The complexity of the Maillard reaction lies in the influence of the flavour formation of several factors, such as temperature, $\mathrm{pH}$, time, water activity, reaction media, amino acid, or protein hydrolysates and sugar involved (Taylor \& Linforth, 2010). These factors have led to a change in reaction rate, reaction pathways, and end-product reactions (Fu et al., 2019).

The food industry widely implements the Maillard reaction technology to improve appearance, similar aroma, and taste characteristics of heat-treated products such as meat, chocolate, coffee, caramel, popcorn, or bread (Taylor \& Linforth, 2010). Also, the Maillard reaction plays an essential role in the food chemical process to develop tasty flavour by carbonyl of sugar-reducing and amino acid or peptide to produce a unique flavour in roasted meat and baked bread (Damodaran et al., 2007). The past few years, the increased study showed the Maillard reaction products (MRPs) derived from food protein peptides contribute to the flavour, colour, and bioactive properties of foods (Jiang et al., 2013; Karnjanapratum et al., 2016; Song et al., 2017; Yu et al., 2018; Fu et al., 2019). The flavour of MRPs mainly relies on different types of reducing sugar and amino acid Maillard, such as producing meat aroma synthesis or barbecue shrimp essence (Luo et al., 2014).

\section{A. Preparation of Maillard Reaction Products (MRPs)}

The preparation of MRPs can be carried out in either wet or dry-heating treatment. Dry-heating is initiated by combining sugar powders and peptides, followed by heat treatment at a specific temperature and relative humidity conditions (Kato et al., 1993). Qi et al. (2010) stated the Maillard reaction in the dry state is relatively limited due to the time-consuming process and irregular contact of raw materials. On the other hand, wet-heating treatment involves a peptide-sugar mixture in aqueous-based solutions heated at a specific temperature and typically employed in altering peptides via the Maillard reaction (O'Mahony et al., 2017). The Maillard reaction-induced modifications of food protein-derived peptides play a vital role in their flavour and bioactivity (Van Lancker et al., 2011). Also, the peptide chain length, peptide composition, sequence, and MRPs. Among the numerous existing protein modification methods, the glycation of proteins induced by sugar conjugation via the Maillard reaction (MR) is widely recognized as the best mechanism for improving functional properties in food proteins (Abdelhedi et al., 2017). 


\section{B. Flavour Properties of Maillard Reaction \\ Products (MRPs) Derived from Peptides}

Table 1. Summary of the recent studies on flavour properties of Maillard reaction products generated from marine protein hydrolysates/peptides and carbohydrates sources

\begin{tabular}{|c|c|c|c|c|}
\hline $\begin{array}{c}\text { Protein } \\
\text { hydrolysates/ } \\
\text { Peptides }\end{array}$ & Carbohydrate & $\begin{array}{l}\text { Reaction } \\
\text { condition }\end{array}$ & Flavour properties & References \\
\hline $\begin{array}{l}\text { Antarctic krill } \\
\text { hydrolysates }\end{array}$ & D-xylose & $\begin{array}{c}105^{\circ} \mathrm{C}, 50 \mathrm{mins} \\
\mathrm{pH} 8.5\end{array}$ & $\begin{array}{c}\text { Addition of roast, } \\
\text { sweetness, and shrimp } \\
\text { meat odours }\end{array}$ & Zhang et al. (2020) \\
\hline $\begin{array}{c}\text { Mud clam } \\
\text { (Polymesoda erosa) } \\
\text { hydrolysates }\end{array}$ & D-xylose & $\begin{array}{c}120^{\circ} \mathrm{C}, 2 \mathrm{~h} \\
\mathrm{pH} 7.4\end{array}$ & $\begin{array}{l}\text { Intense umami and less } \\
\text { fishy taste }\end{array}$ & $\begin{array}{c}\text { Normah and } \\
\text { Noorasma (2018) }\end{array}$ \\
\hline $\begin{array}{l}\text { Smoothhound } \\
\text { viscera hydrolysates }\end{array}$ & Sucrose & $90^{\circ} \mathrm{C}, 2 \mathrm{~h}$ & Reduce bitter taste & $\begin{array}{l}\text { Abdelhedi et al. } \\
\qquad(2017)\end{array}$ \\
\hline $\begin{array}{l}\text { Chinese shrimp } \\
\text { waste hydrolysates }\end{array}$ & Xylose & $\begin{array}{c}115^{\circ} \mathrm{C}, 3 \mathrm{~h} \\
\mathrm{pH} 8\end{array}$ & $\begin{array}{l}\text { Strong meaty aroma, } \\
\text { umami and mouthfulness } \\
\text { taste }\end{array}$ & Cai et al. (2016) \\
\hline $\begin{array}{l}\text { Fish muscle } \\
\text { (Collichthys } \\
\text { niveatus) } \\
\text { hydrolysate }\end{array}$ & $\begin{array}{l}\text { Glucose and } \\
\text { Xylose }\end{array}$ & $\begin{array}{c}120^{\circ} \mathrm{C}, 1 \mathrm{~h} \\
\mathrm{pH} 8.5\end{array}$ & $\begin{array}{l}\text { Toasty, nutty and sweet } \\
\text { caramel-like aroma }\end{array}$ & Zhao et al. (2016) \\
\hline $\begin{array}{l}\text { Cod byproduct } \\
\text { hydrolysates }\end{array}$ & Xylose & $80^{\circ} \mathrm{C}, 1.5 \mathrm{~h}$ & $\begin{array}{l}\text { Increased fish sauce-like } \\
\text { flavour }\end{array}$ & $\begin{array}{l}\text { Min and Einarsson } \\
(2015)\end{array}$ \\
\hline $\begin{array}{l}\text { Salmon } \\
\text { hydrolysates }\end{array}$ & Xylose & $\begin{array}{c}45-50^{\circ} \mathrm{C} \\
4-6 \mathrm{~h} \\
\mathrm{pH} 5.4-7.5 \\
\end{array}$ & $\begin{array}{l}\text { Masking fish odour, sweet } \\
\text { and aromatic notes }\end{array}$ & Kouakou et al. (2014) \\
\hline
\end{tabular}

The flavour is a crucial element in determining the quality and consumer acceptability. Significantly, protein hydrolysates or peptides may contribute to the taste and aroma of food through the direct pathway, heat degradation, Maillard reaction, or collaboration with other food ingredients (Temussi, 2012). Peptides are known as significant flavour enhancers and precursors of the Maillard reaction (Van Lancker et al., 2011). MRPs are widely used in producing a variety of flavour enhancers and the proposed excellent flavour enhancers may possess a good mouthfulness and continuity of the flavour (Eric et al., 2013). A growing number of studies recently showed the MRPs produced from protein hydrolysates or peptides and carbohydrates affected the flavour properties of food products. Several studies reported the MRPs of protein hydrolysates could impart longlasting and complex flavours (Zhang et al., 2020; Karangwa et al., 2015). The flavour properties of MRPs obtained from fishery protein hydrolysates or peptides and carbohydrates are briefly described in Table 1.

\section{Taste-active of Maillard Reaction Products (MRPs) derived from peptides}

The MRPs formed from peptides suggested exhibiting an improved effect on the taste of food. During thermal treatment of reducing sugar and peptide, peptide undergoes two chemical changes as peptide degrades to a smaller fraction and amino acids. On the other side, a peptide can be directly interlinked with sugar (Lan et al., 2010). Hence, the higher amount of amino acids in MRPs indicated the crosslinking process is dominant in thermal reactions of peptide fractions with xylose and caused in the increment of umaminess (Liu et al., 2012). Besides, the taste-enhancing potential of MRPs developed from xylose and hydrolyzed soybean protein isolated from the 1000 to 5000 Da fraction likely increased the intensity of mouthfulness and continuity in umami solution and consomme soup (Ogasawara et al., 2006). Similarly, the Maillard reaction of D-xylose toward Mud clam (Polymesoda erosa) hydrolysates has more intense umami and less fishy taste (Normah \& Noorasma, 2018). Karangwa et al. (2016) revealed the taste-enhancing properties of MRPs are attributed to both crosslinking and Maillard reacted peptides which produced 'kokumi' sensation. Cai et al. (2016) expressed the Chinese shrimp waste hydrolysates have a strong meaty aroma, umami, and mouthfulness taste. Moreover, the cod byproduct hydrolysates are increased in fish sauce-like taste (Min \& Einarsson, 2015).

Song et al. (2013) also claimed the enzymatic crosslinking via microbial transglutaminase (MTGase) has been employed to increase the yield of MRPs (1-5 kDa) from soybean protein 
hydrolysates that responsible for mouthfulness and reduced bitterness. The bitter taste of the smoothhound viscera hydrolysates is reduced after the Maillard reaction (Abdelhedi et al., 2017). Furthermore, the glucosamineinduced glycation of poultry protein hydrolysates in the presence of MTGase found out enhanced savoury taste (Hong et al., 2016). Idowu and Benjakul (2019) expressed that the MTGase is notable for improving proteins via the addition of amine, crosslinking, and deamination. Liu et al. (2017) indicated deamination-induced modification of wheat gluten hydrolysates produced deaminated WGH with improved umami and less bitter taste. The sensory attributes of MRPs from sunflower protein hydrolysates, xylose, and cysteine also showed good flavour and taste (Eric et al., 2013). The formation of 2,5-Diketopiperazines (2,5-DKPs) as thermal reaction byproducts accompanied by Maillard reaction referred to cyclic dipeptides, known as the source of the tasteactive compound in processed food. The use of 2,5-DKPs indicated to develop astringent, salty, metallic, or bitter taste and have been identified in various foods such as meat, milk, pizza, chocolate, chicken, and roasted coffee (Borthwick \& Da Costa, 2017). Therefore, the Maillard reaction in hydrolysates may assist in reducing the bitterness to some extent.

\section{Aroma-active of Maillard Reaction Products (MRPs) derived from peptides}

The Maillard reaction is responsible for producing unique aromas during thermal treatment and substantially improved food products (Sun et al., 2010). The aroma characteristic is influenced not only by the species but also by the conditions used during post-harvest handling, storage, and cooking. Commonly, some fish such as salmon or trout have a strong flavour and relatively mild smell before cooking, which becomes intense and pleasant after heating (Ganeko et al., 2008a). The roasting aroma has traditionally been regarded as the predominant flavour (MacLeod \& Coppock, 1977). These unique aromas are closely associated with raw material in the system, such as roasted flavour in meat (Domínguez et al., 2014) and seafood flavour in marine products (Kubota et al., 2002). Van Boekel (2006) expressed the Maillard reaction can produce numerous volatile compounds. The peptides contribute to several specific aroma compounds forming compared to free amino acids (Van Lancker et al., 2011).

The study of the Maillard reaction by pure peptide models has shown that peptides are involved in the response of Maillard in several processes, including bond cleavage, cyclization, and glycation (Liu et al., 2015; Yang et al., 2012). Zhang et al. (2020) stated the Antarctic krill hydrolysates generated the addition of roast, sweetness, and shrimp meat odours after the Maillard reaction. The fish muscle (Collichthys niveatus) hydrolysate is produced a toasty, nutty, and sweet caramel-like aroma (Zhao et al., 2016). Kouakou et al. (2014) suggested the Maillard reaction is masking fish odour, give sweet and aromatic noted in the salmon hydrolysate. The formation of the specific volatile compounds during the Maillard reaction is strongly dependent on the distribution of the molecular weight of hydrolysates, composition, and configuration of peptides (Song et al., 2013). Since protein hydrolysates produce a large number of peptides, it is reasonable that MRPs derived from protein hydrolysates can exhibit a broad range of aroma.

Fu et al. (2019) demonstrated that the MRPs of peptide and sugars possess a strong meaty-like flavour due to the development of specific aromas such as pyrazines and pyrazinones thiazoles, and thiophenes. Pyrazines, nitrogencontaining heterocyclic compounds referred to as nutty, coffee, and roast meat-like odours (Liu et al., 2015; Van Lancker et al., 2012). Pyrazines contribute to full-body flavours that essential as food additives in meat and condiments (Shahidi, 1998). The formation of pyrazine mechanisms involves $\alpha$-aminoketones produced by condensation of dicarbonyl compounds with amino compounds during the Maillard reaction (Van Lancker et al., 2010). Additionally, it can be speculated more pyrazines can be produced in the glucose-dipeptide model system compared to free amino acids. Van Lancker et al. (2012) indicated that N-terminal amino acid peptides' structural properties are crucial for the increased development of pyrazines. Recent experiments have shown the low molecular weight peptides $(<500 \mathrm{Da})$ are known to be the most significant contributor to pyrazine production due to the high reaction activity of amidogen (Liu et al., 2015). The impact of peptides on pyrazine formation during the Maillard reaction is essential and remains further investigated. 
Pyrazinones with unique toasted aroma are peptide-specific MRPs derived during the Maillard reaction of dicarbonyls (glyoxal or methylglyoxal) with glycine dipeptide. They cannot be generated in the free amino acid system (Izzo \& Ho, 1992). The formation of pyrazinone mechanisms is based on the glycine dipeptide model using glucose and dicarbonyl compounds labeled as two possible pathways involved in pyrazinones formation. In pathway A, glyoxal, and pyruvaldehyde are required to generate dimethylpyrazinones and trime-thylpyrazinones, respectively. It then incorporates three glycine molecules into the pyrazinone structure. On the other hand, the number of glycine molecules included in Pathway B depends on whether pyruvaldehyde and 2,3butanedione, derived from amadori compounds or produced by trans-forming glyoxal and pyruvaldehyde by glycine (Keyhani \& Yaylayan, 1996). Mainly, pyrazines and pyrazinones, sulfur-containing heterocyclic compounds (e.g. thio-phenes and thiazoles) produced during the Maillard reaction or Stretcher degradation may serve as major volatile compounds with roasted and meaty aromas (Jayasena et al., 2013). During the Maillard reaction, $\mathrm{H}_{2} \mathrm{~S}$ released from Scontaining amino acids may react with MRPs, resulting in an array of S-containing compounds (Van Lancker et al., 2011). Due to the relatively low odour thresholds, these compounds may significantly contribute to the overall aroma of food (Mottram, 1998).

Background studies showed the protein hydrolysates and reducing sugar exhibit a pleasant flavour via MRPs. Aside from the typical Maillard aroma compound, the Strecker degradation occurs between amino acids, and the dicarbonyl compound may confer pungent, unpleasant, and burnt aroma. Additionally, a rich supply of oxygen-containing heterocyclic compounds may be formed, including furans and furfurals, which provide flavour characteristics ( $\mathrm{Fu}$ et al., 2019).

\section{E. Bioactive Properties of MRPs Generated from Peptides}

Last decade, a growing number of studies indicated peptides derived via the Maillard process have various bioactivities, including antibacterial activity, antioxidant activity, antihypertensive activity, or anticancer properties (Wu et al., 2014; Yamabe et al., 2016; Zhang et al., 2016; Li et al., 2016).
Besides, certain MRPs bioactivities have been confirmed using in vivo animal and human clinical trials. Recently, the accumulative evidence has indicated an antioxidant activity and some other biological activities of MRPs triggered by reactions between various sources of protein hydrolysates and carbohydrates, as summarized in Table 2 and Table 3, respectively.

Vhangani and Van Wyk (2016) expressed the MRPs may exhibit potent antioxidant activity that confers potential as a substitute for synthetic antioxidants. The antioxidant function of MRPs has been reported in the glucose and glycine or sodium glutamate reaction model. It documented the MRPs produced by protein hydrolysates/peptides are said to have antioxidant activity that appears to have substantially increased antioxidant activity compared to protein hydrolysate/peptide alone (Bai et al., 2017; Zhang et al., 2018). The higher antioxidant activity with Maillardderived MRPs is between reducing sugars (glucose and xylose) and Gly-His dipeptides relative to MRPs obtained with His-Gly dipeptides (Lingnert \& Eriksson, 1980). Previous studies also reported the results of MRPs derived from the fructose-amino acid model system showed higher biological activities than glucose-amino acid model system, especially in sugar-tryptophan and -tyrosine MRPs exerted higher biological activities than the other MRPs (Giroux et al., 2010; Hwang et al., 2011).

This indicated the antioxidant efficacy of MRPs depends on not only amino acid composition, but also the chain length of the peptide sequence (Lingnert \& Eriksson, 1980). In addition, the peptide chain length and peptide bond stability against heat treatment is linked to the antioxidant activity of MRPs. Background research stated the antioxidant activity of MRPs prepared from the model glucose systems with glycine, diglycine, and triglycine has been observed that MRPs from diglycine model system showed the most potent antioxidant activity. In view of the MRPs complexity, a variety of compounds in MRPs can exhibit antioxidant activity by different mechanisms, including reducing power ability, free radical scavenging, metal ion chelating, and intracellular antioxidant enzyme control in vivo (Vhangani \& Van Wyk, 2016). It appears that low molecular weight MRPs tend to exhibit antioxidant effects in the body after they have been absorbed by the small intestine (Silva'n et al., 2006). 
Table 2. Summary of the recent studies on the antioxidant activities of Maillard reaction products generated from marine protein hydrolysates/peptides and carbohydrates sources

\begin{tabular}{|c|c|c|c|c|}
\hline $\begin{array}{c}\text { Protein } \\
\text { hydrolysates/ } \\
\text { peptides }\end{array}$ & Carbohydrate & $\begin{array}{l}\text { Reaction } \\
\text { condition }\end{array}$ & Antioxidant activity & References \\
\hline Smooth hound viscera & Sucrose & $90^{\circ} \mathrm{C}, 2 \mathrm{~h}$ & $\begin{array}{l}\beta \text {-carotene bleaching assay, } \\
\text { Reducing power assay }\end{array}$ & $\begin{array}{l}\text { Abdelhedi et al. } \\
\text { (2017) }\end{array}$ \\
\hline $\begin{array}{l}\text { Sea cucumber gut } \\
\text { hydrolysates }\end{array}$ & Ribose & $\begin{array}{c}75^{-9} 95^{\circ} \mathrm{C}, 12 \mathrm{~h}, \\
\mathrm{pH} 7 \text { or } \mathrm{pH} 8\end{array}$ & DPPH radical scavenging activity & Han et al. (2017) \\
\hline $\begin{array}{l}\text { Shrimp byproduct } \\
\text { protein hydrolysates }\end{array}$ & Glucose & $\begin{array}{l}110^{\circ} \mathrm{C}, 10 \mathrm{~h}, \\
\mathrm{pH} 6.5\end{array}$ & $\begin{array}{l}\text { DPPH scavenging activity, oxygen } \\
\text { radical absorbance capacity, } \\
\text { intracellular ROS in HepG2 cells }\end{array}$ & Zha et al. (2015) \\
\hline $\begin{array}{l}\text { Squid byproduct } \\
\text { hydrolytic peptides }\end{array}$ & D-arabinose & $\begin{array}{c}105^{\circ} \mathrm{C}, 20-30 \\
\min , \mathrm{pH} 13\end{array}$ & $\begin{array}{c}\text { Hydroxyl radical scavenging } \\
\text { activity, ABTS radical scavenging, } \\
\text { Reducing power }\end{array}$ & Jiang et al. (2018) \\
\hline
\end{tabular}

Table 3. Summary of the recent studies on the various bioactivities of Maillard reaction products generated from $\mathrm{m}$ arine protein hydrolysates/peptides and carbohydrates sources

\begin{tabular}{|c|c|c|c|c|}
\hline $\begin{array}{c}\text { Protein } \\
\text { hydrolysates/ } \\
\text { peptides }\end{array}$ & Carbohydrate & $\begin{array}{l}\text { Reaction } \\
\text { condition }\end{array}$ & Antioxidant activity & References \\
\hline $\begin{array}{l}\text { Half-fin anchovy } \\
\text { hydrolysates }\end{array}$ & Glucose & $\begin{array}{l}120^{\circ} \mathrm{C}, 100 \\
\min , \mathrm{pH} 9\end{array}$ & Antibacterial activity & Song et al. (2017) \\
\hline $\begin{array}{l}\text { Leatherjacket skin } \\
\text { gelatin } \\
\text { hydrolysates }\end{array}$ & Galactose & $70^{\circ} \mathrm{C}, 35 \mathrm{~h}$ & $\begin{array}{l}\text { In vitro immunomodulatory } \\
\text { properties and anticancer } \\
\text { activity }\end{array}$ & $\begin{array}{c}\text { Karnjanapratum et } \\
\text { al. (2017) }\end{array}$ \\
\hline $\begin{array}{l}\text { Flatfish byproduct } \\
\text { hydrolysates }\end{array}$ & Ribose & $\begin{array}{l}121^{\circ} \mathrm{C}, 38.09 \\
\min , \mathrm{pH} 8.26\end{array}$ & Anti-inflammatory activity & Choe et al. (2015) \\
\hline $\begin{array}{l}\text { Fish protein } \\
\text { hydrolysates }\end{array}$ & $\begin{array}{c}\text { Galacto- } \\
\text { oligosaccharide }\end{array}$ & $\begin{array}{l}80^{\circ} \mathrm{C}, 120 \\
\mathrm{~min}, \mathrm{pH} 7\end{array}$ & Beneficial effect on rat gut & Jin et al. (2018) \\
\hline $\begin{array}{l}\text { Squid byproducts } \\
\text { hydrolytic peptides }\end{array}$ & D-arabinose & $\begin{array}{c}105^{\circ} \mathrm{C}, 20-30 \\
\min , \mathrm{pH} 13\end{array}$ & Antibacterial activity & Jiang et al. (2018) \\
\hline
\end{tabular}

According to Chuyen et al. (1998), in vivo antioxidant activity of MRPs is confirmed made from peptide-glucose mixtures. These MRPs had potent scavenging activity against reactive oxygen species (ROS), which plays a vital role in the in vivo antioxidant function of MRPs. Apart from that, melanoidins have been identified as responsible for the antioxidant activity of MRPs due to heterocyclic compounds and reductones produced by the Maillard reaction (Kanzler $e t$ al., 2016). Melanoidins are classified as high molecular weight, nitrogen-containing, and brown-coloured compounds formed in the late stages of the Maillard reaction (Mesías \& Delgado-Andrade, 2017). Three main chemical structures of melanoidins are proposed, including polymers consisting of repeating units of furans and/or pyrrol, crosslinking products with low molecular-weight coloured substances, and sugar degradation products interlinked with amino compounds (Cämmerer et al., 2002). Another claimed that the critical antioxidant function of melanoidins is the metal-chelating capacity due to its anionic hydrophilic nature, which can form stable metal cation complexes (Morales et al., 2005).

Kanzler et al. (2016) verified the antioxidant activities of several main dicarbonyl compounds and heterocyclic intermediates are based on different approaches. Their potential for antioxidant pathways may be attributed to their position as electron donors (Kanzler et al., 2016). Meanwhile, reductones are found in the intermediate stage of the Maillard reaction (Garbe et al., 2008). Some MRPs comprising reductone-like structures and exhibiting reducing properties have been reported, including dicarbonyl compounds and heterocyclic intermediates (Kanzler et al., 2017). The reaction of the Maillard reaction leads to the formation of many important nitrogen-containing heterocyclic compounds, such as furans, pyrroles, pyrazines, and thiazoles, which have been discovered to correlate with reducing power and $\mathrm{Fe}^{2+}$ chelating activity (Liu et al., 2012). The heterocyclic aromatic ring has a high electron density of carbon atoms capable of scavenging free radicals (Shaker et 
al., 1995). It is believed the addition of an electron-donating group ( e.g. a methyl group) can increase the electron density of carbon atoms of the q nucleophilic thiol group, either as a single electron-reducing agent for the scavenge of peroxyl and alkoxy1 radicals, or as a two-electron-reducing and subsequent disulfide formation of hydroperoxides (Shaker et al., 1995).

Apart from the antioxidant activities, the MRPs from peptides have been documented to exert antimicrobial effects. The MRPs against different bacteria strains, such as Bacillus subtilis, Escherichia coli, Staphylococcus aureus, Listeria monocytogenes, Shigella dysenteriae, and Salmonella typhimurium, is documented (Hauser et al., 2014; Chung et al., 2011). The MRPs of fish gelatin hydrolysates showed specificity towards inhibition of Escherichia coli (Hong et al., 2014). Moreover, the MRPs obtained from half-fin anchovy hydrolysates/glucose model system exhibited antibacterial activities against several microorganisms, such as Escherichia coli, Pseudomonas fluorescens, Proteus vulgaris, Pseudomonas aeruginosa, Staphylococcus aureus, Bacillus subtilis, Bacillus megaterium, and Sarcina lutea (Song et al., 2016). Song et al. (2017) subsequently identified seven antibacterial peptide sequences, including RVAPEEHPTL, WLPVVR, FFTQATDLLSR, VLLLWR, VLLVLLR, VLLALWR, and LLSWYDNEFGYSNR.

Choe et al. (2016) demonstrated the MRPs derived from protein hydrolysates of flatfish byproduct and ribose possess anti-inflammatory effects by suppressing lipopolysaccharide (LPS)-induced development of nitric oxide and prostaglandin E2 as well as the expression of inducible nitric oxide synthase and cyclooxygenase-2 in RAW 264.7 mouse macrophage cells. It hypothesized that the nuclear factor kappa B (NF-jB) and mitogen-activated protein kinase (MAPK) signaling pathways are involved in the anti-inflammatory activity of MRPs (Choe et al., 2016). Similarly, MRP developed from unicorn leather jacket gelatin hydrolysate and galactose revealed anti-inflammatory activity by decreasing proinflammatory cytokine expression (interleukin-6 and interleukin-1b) and nitric oxide production in LPS-induced RAW 264.7 cells (Karnjanapratum et al., 2016).

Generally, gut homeostasis is considered necessary for maintaining gut health. Modification of protein hydrolysates/peptides by the Maillard reaction can boost resistance toward digestive enzymes and reduce gastrointestinal digestibility, which allows more place for gut microbiota to utilize and fermented by these MRPs (Hernandez-Hernandez et al., 2011). Recently, the grass carp fish hydrolysates glycated with galactooligosaccharide has been reported can modify the pattern of SCFA development in the hindgut of rats with increased levels of total SCFA, butyrate, and propionate in the proximal colon as well as the butyrate levels (74\%) in the distal colon of rats (Jin et al., 2018).

\section{CONCLUSION}

Finding for an effective approach for flavour enhancement and debittering without affecting the quality of protein hydrolysates becomes increasingly important. Owing to the unique molecular structures and formation mechanisms of peptide-specific MRPs, they lead to the unique creation of flavour during processing and storage. This review reveals the Maillard reaction is provided with an upgradable process for debittering and fishy flavour removal. Besides, the subsequent knowledge of the structure-function relationship of MRPs is essential in advancing the research on bioactive food protein hydrolysates and peptides in order to develop the market of the peptides as natural health products and nutraceuticals.

\section{ACKNOWLEDGEMENT}

The study was financially supported by Bridging Grant with grant number 6316287 obtained from Universiti Sains Malaysia. Financial assistance of the Graduate Assistance scheme from Universiti Sains Malaysia for author Ayu Shazwani Zulkipli was gratefully acknowledged. 


\section{REFERENCES}

Abdelhedi, O, Mora, L, Jemil, I, Jridi, M, Toldrá, F, Nasri, M \& Nasri, R 2017, 'Effect of ultrasound pretreatment and Maillard reaction on structure and antioxidant properties of ultrafiltrated smooth-hound viscera proteins-sucrose conjugates', Food Chemistry, vol. 230, pp. 507-515.

Allen, TM \& Cullis, PR 2013, 'Liposomal drug delivery systems: from concept to clinical applications', Advanced Drug Delivery Reviews, vol. 65, pp. 36-48.

Ayu Shazwani Zulkipli \& Rabeta Mohd Salleh 2020, 'Enzymatic hydrolysis as an approach to produce alternative protein from cephalopods ink powder: a short review', Food Research, vol. 4(October), pp. o-3o.

Bai, W, Wang, Q, Zeng, X, Fu, J, Liu, Y \& Dong, H 2017, 'Antioxidant activities of chicken peptide-Maillard reaction products (CP-MRPS) derived from chicken peptides and dglucose system', Journal of Food Processing and Preservation, vol. 41, no. 2, pp. e13041.

Borthwick, AD \& Da Costa, NC 2017, '2,5-diketopiperazines in food and beverages: Taste and bioactivity', Critical Reviews in Food Science and Nutrition, vol. 57, no. 4, pp. 718-42.

Cai, L, Li, D, Dong, Z, Cao, A, Lin, H \& Li, J 2016, 'Change regularity of the characteristics of Maillard reaction products derived from xylose and Chinese shrimp waste hydrolysates', LWT - Food Science and Technology, vol. 65, pp. 908-916.

Cämmerer, B, Jalyschko, W \& Kroh LW, 2002, 'Intact carbohydrate structures as part of the melanoidin skeleton', Journal of Agricultural and Food Chemistry, vol. 50, no. 7 , pp. 2083-7.

Cheung, RCF, Ng, TB, Wong, JH 2015, 'Marine peptides: bioactivities and applications', Marine drugs, vol. 13, no. 7, pp. 4006-4043

Choe, IH, Jeon, HJ, Eom, SH, Han, YK, Kim, YS \& Lee SH 2016, 'The anti-inflammatory effect of a glycosylation product derived from the high hydrostatic pressure enzymatic hydrolysate of a flatfish byproduct', Food \& Function vol. 7, no. 6, pp. 2557-65.

Chung, YC, Yeh, JY \& Tsai CF 2011, 'Antibacterial characteristics and activity of water-soluble chitosan derivatives prepared by the Maillard reaction', Molecules, vol. 16, no. 10, pp. 8504-14.

Chuyen, N, Ijichi, K, Umetsu, H \& Moteki, K 1998, 'Antioxidative properties of products from amino acids or peptides in the reaction with glucose', Process-induced chemical changes in food, 201-12. Boston, MA: Springer.

Clemente, A 2000, 'Enzymatic protein hydrolysates in human nutrition', Trends Food Sci Tech, vol. 11, no. 7, pp. 254-262. Damodaran, S, Parkin, KL \& Fennema, OR 2007, Fennema's Food Chemistry (Fourth Edition), CRC Press.

Domínguez, R, Gómez, M, Fonseca, S \& Lorenzo, JM 2014, 'Effect of different cooking methods on lipid oxidation and formation of volatile compounds in foal meat', Meat science, vol. 97, no. 2, pp. 223-230.

Eric, K, Raymond, LV, Huang, M, Cheserek, MJ, Hayat, K, Savio, ND, Zhang, X 2013, 'Sensory attributes and antioxidant capacity of Maillard reaction products derived from xylose, cysteine and sunflower protein hydrolysate model system,' Food Research International, vol. 54, no. 2, pp. 1437-1447.

Ezquerra-Brauer, JM \& Aubourg, SP, 2019, 'Recent trends for the employment of jumbo squid (Dosidicus gigas) byproducts as a source of bioactive compounds with nutritional, functional and preservative applications: a review, International Journal of Food Science and Technology, vol. 54, no. 4, pp. 987-998.

Food and Agriculture Organization (FAO) 2019, Fishery and Aquaculture Country Profiles. Malaysia (2009)' Country Profile Fact Sheets. In: FAO Fisheries and Aquaculture Department [online], Rome, viewed 20 September 2019, <http://www.fao.org/fishery/>

Fu, Y, Liu, J, Hansen, ET, Bredie, WLP \& Lametsch, R 2018b, 'Structural characteristics of low bitter and high umami protein hydrolysates prepared from bovine muscle and porcine plasma', Food Chemistry, vol. 257, pp. 163-171.

Fu, Y, Chen, J, Bak, KH \& Lametsch, R 2019, 'Valorisation of protein hydrolysates from animal byproducts: perspectives on bitter taste and debittering methods: a review', International Journal of Food Science and Technology, vol. 54, no. 4, pp. 978-986.

Fujimaki, M, Yamashita, M, Arai, S \& Kato, H 1970, 'Plastein reaction: its application to debittering of proteolyzates', Agricultural and Biological Chemistry, vol. 34, pp. 483484 .

Gajanan, PG, Elavarasan, K \& Shamasundar, BA 2016, 'Bioactive and functional properties of protein hydrolysates from fish frame processing waste using plant proteases', 
Environmental Science and Pollution Research, vol. 23, no. 24, pp. 24901-24911.

Ganeko, N, Shoda, M, Hirohara, I, Bhadra, A, Ishida, T, Matsuda, H, \& Matoba, T 2008, 'Analysis of volatile flavour compounds of sardine (Sardinops melanostica) by solid phase microextraction', Journal of Food Science, vo. 73, no. 1, pp. S83-S88.

Garbe, LA, Wurtz, A, Piechotta, Ct \& Tressl, R 2008, 'The peptide-catalyzed Maillard reaction - Characterization of 13C reductones', Annals of the New York Academy of Sciences, vol. 1126, no. 1, pp. 244-7.

Gbogouri, GA, Linder, M, Fanni, J \& Parmentier, M 2004, 'Influence of hydrolysis degree on the functional properties of salmon byproducts hydrolysates', Journal of Food Science, pp. 69(8).

Giroux, HJ, Houde, J \& Britten, M 2010, 'Use of heated milk protein-sugar blends as antioxidant in dairy beverages enriched with linseed oil', LWT - Food Science and Technology, vol. 43, pp. 1373-1378.

Hauser, C, Müller, U, Sauer, T, Augner, K \& Pischetsrieder, M 2014, 'Maillard reaction products as antimicrobial components for packaging films', Food Chemistry, vol. 145, pp. 608-13.

Hernandez-Hernandez, O, Moreno, FJ, Kolida, S, Rastall, RA \& Sanz, ML 2011, 'Effect of glycation of bovine betalactoglobulin with galactooligosaccharides on the growth of human faecal bacteria', International Dairy Journal, vol. 21, no. 12 , pp. $949-52$.

Hong, PK, Gottardi D, Ndagijimana, M \& Betti, M 2014, 'Glycation and transglutaminase mediated glycosylation of fish gelatin peptides with glucosamine enhance bioactivity', Food Chemistry, vol. 142, no. 285-93.

Hong, PK, Ndagijimana, M \& Betti, M 2016, 'Glucosamineinduced glycation of hydrolysed meat proteins in the presence or absence of transglutaminase: Chemical modifications and taste-enhancing activity', Food Chemistry, vol. 197, no. 4, pp. 1143-1152.

Hwang, IG, Kim, HY, Woo, KS, Lee, J \& Jeong, HS 2011, 'Biological activities of Maillard reaction products (MRPs) in a sugar-amino acid model system', Food Chemistry, vol. 126, pp. 221-227.

Idowu, AT \& Benjakul, S 2019, 'Bitterness of fish protein hydrolysate and its debittering prospects', Journal of Food Biochemistry, vol. 43, no. 9, pp. 1-10.

Izzo, HV \& Ho, CT 1992, 'Peptide-specific Maillard reaction products: A new pathway for flavour chemistry', Trends in Food Science \& Technology, vol. 3, pp. 253-7.
Jayasena, DD, Ahn, DU, Nam, KC \& Jo, C 2013, 'Flavour chemistry of chicken meat: a review', Asian-Australasian Journal of Animal Sciences, vol. 26, no. 5, pp. 732.

Jiang, W, Liu, Y, Yang, X, Wang, P, Hu, S \& Li, J 2018, 'Recovery of Proteins from Squid By-Products with Enzymatic Hydrolysis and Increasing the Hydrolysate's Bioactivity by Maillard Reaction', Journal of Aquatic Food Product Technology, vol. 27, no. 8, pp. 900-911.

Jiang, Z, Wang, L, Wu, W \& Wang, Y 2013, 'Biological activities and physicochemical properties of Maillard reaction products in sugar-bovine casein peptide model systems', Food chemistry, vol. 141, no. 4, pp. 3837-3845.

Jin, WK, Han, S, Dong, Y, Yang, Z, Mao, M, Su \& Zeng M 2018, 'Modifications in gut microbiota and fermentation metabolites in the hindgut of rats after the consumption of galactooligosaccharide glycated with a fish peptide', Food \& Function, vol. 9, no. 5, pp. 2853-64.

Kanzler, C, Haase, PT, Schestkowa, H \& Kroh, LW 2016, 'Antioxidant properties of heterocyclic intermediates of the Maillard reaction and structurally related compounds', Journal of Agricultural and Food Chemistry, vol. 64, no. 41, pp. 7829-37.

Kanzler, C, Schestkowa, H, Haase, PT \& Kroh, LW 2017, 'Formation of reactive intermediates, colour, and antioxidant activity in the Maillard reaction of maltose in comparison to d-glucose', Journal of Agricultural and Food Chemistry, vol. 65, no. 40, pp. 8957-65.

Karangwa, E, Murekatete, N. de Dieu Habimana, J, Masamba, K, Duhoranimana, E, Muhoza, B \& Zhang, X 2016, 'Contribution of crosslinking products in the flavour enhancer processing: The new concept of Maillard peptide in sensory characteristics of Maillard reaction systems', Journal of Food Science and Technology, vol. 53, no. 6, pp. 2863-2875.

Karangwa, E, Zhang, X, Murekatete, N, Masamba, K, Raymond, LV, Shabbar, A, \& Song, S 2015, 'Effect of substrate type on sensory characteristics and antioxidant capacity of sunflower Maillard reaction products', European Food Research and Technology, vol. 240, no. 5, pp. 939-960.

Karnjanapratum, S, O'Callaghan, YC, Benjakul, S \& O'Brien, NM 2016, 'In vitro cellular bioactivities of Maillard reaction products from sugar-gelatin hydrolysate of unicorn leatherjacket skin system', Journal of Functional Foods, vol. 23, pp. 87-94.

Kato, A, Minaki, K \& Kobayashi, K 1993, 'Improvement of emulsifying properties of egg white proteins by the 
attachment of polysaccharide through Maillard reaction in a dry state', Journal of Agricultural and Food Chemistry, vol. 41 , no. 4 , pp. $540-3$.

Kechaou, ES, Bergé, J, Jaouen, P \& Amar, RB 2015, 'Optimization of Common Cuttlefish (Sepia officinalis) Protein Hydrolysate Using Pepsin by Response Surface Methodology Optimization of Common Cuttlefish (Sepia officinalis) Protein Hydrolysate Using Pepsin by Response Surface Methodology', Journal of Aquatic Food Product Technology, vol. 24, no. 3, pp. 270-282.

Keyhani, A \& Yaylayan, VA 1996, 'Elucidation of the mechanism of pyrazinone formation in glycine model systems using labeled sugars and amino acids', Journal of Agricultural and Food Chemistry, vol. 44, no. 9, pp. 25112516.

Kim, HO \& Li-Chan, EC 2006, 'Quantitative structure activity relationship study of bitter peptides', Journal of Agricultural and Food Chemistry, vol. 54, no. 26, pp. 1010210111.

Kouakou, C, Bergé, JP, Baron, R, Lethuaut, L, Prost, C \& Cardinal, M 2014, 'Odour modification in salmon hydrolysates using the Maillard reaction', Journal of Aquatic Food Product Technology, vol. 23, no. 5, pp. 453467.

Kristinsson, HG \& Rasco, BA 2000, 'Fish protein hydrolysates: production, biochemical, and functional properties', Critical Reviews in Food Science and Nutrition, vol. 40, no. 1, pp. 43-81.

Kubota, S, Itoh, K, Niizeki, N, Song, XA, Okimoto, K, Ando, M, \& Sakaguchi M 2002, 'Organic taste-active components in the hot-water extract of yellowtail muscle', Food Science and Technology Research, vol. 8, no. 1, pp. 45-49.

Lan, XH, Liu, P, Xia, SQ, Jia, CS, Mukunzi, D, Zhang, XM, Xia, WS, Tian, HX \& Xiao, ZB 2010, 'Temperature effect on the non-volatile compounds of Maillard reaction products derived from xylose-soybean peptide system: Further insights into thermal degradation and crosslinking', Food Chemistry, vol. 120, no. 4, pp. 967-72.

Li Chan, EC \& Cheung, IW 2010, Flavor-active properties of amino acids, peptides, and protein. In Y. Mine, E. Li Chan, \& B. Jiang (Eds.), Bioactive Proteins and Peptides as Functional Foods and Nutraceuticals (pp. 341-358). Iowa, USA:Wiley-Blackwell. doi:10.1002/9780813811048.

Li, FJ, Liu, WL, Yamaki, K, Liu, YH, Fang, YY, Li, ZJ, Chen, MH \& Wang, CL 2016, 'Angiotensin I-Converting Enzyme Inhibitory Effect of Chinese Soypaste along Fermentation and Ripening: Contribution of Early Soybean Protein Borne
Peptides and Late Maillard Reaction Products', Int. J. Food Prop, vol. 19, no. 12, pp. 2805-2816.

Li, Z, Paulson, AT \& Gill, TA 2015, Encapsulation of bioactive salmon protein hydrolysates with chitosan-coated liposomes. Journal of Functional Foods, vol. 19, pp. 733743

Lingnert, H \& Eriksson, C 1980, 'Antioxidative Maillard reaction products. II. Products from sugars and peptides or protein hydrolysates', Journal of Food Processing and Preservation, vol. 4, no. 3, pp. 173-81.

Liu, BY, Zhu, KX, Guo, XN, Peng, W \& Zhou, HM 2017, 'Effect of deamidation-induced modification on umami and bitter taste of wheat gluten hydrolysates', Journal of the Science of Food and Agriculture, vol. 97, no. 10, pp. 3181-3188.

Liu, J, Liu, M, He, C, Song, H \& Chen, F, 2015, 'Effect of thermal treatment on the flavour generation from Maillard reaction of xylose and chicken peptide', LWT-Food Science and Technology, vol. 64, no. 1, pp. 316-325.

Liu, P, Huang, M, Song, S, Hayat, K, Zhang, X, Xia, S \& Jia, C 2012, 'Sensory characteristics and antioxidant activities of Maillard reaction products from soy protein hydrolysates with different molecular weight distribution', Food and Bioprocess Technology, vol. 5, no. 5, pp. 1775-1789.

Luo, W, Duan, ZH, Wan, B \& Hu, J 2014, 'Research of preparing seafood flavour applying maillard reaction products derived from the hydrolysate of mussel juice', BioTechnology an Indian Journal, vol. 10, no. 24, pp. 15175-15183.

MacLeod, G \& Coppock, BM 1977, 'A comparison of the chemical composition of boiled and roasted aromas of heated beef', Journal of Agricultural and Food Chemistry, vol. 25 , no. 1 , pp. 113-117.

Mesías, M \& Delgado-Andrade, C 2017, Melanoidins as a potential functional food ingredient. Current Opinion in Food Science, vol. 14, pp. 37-42.

Min, Q \& Einarsson, H 2015,' Savoury Flavour Formulations from Maillard Reaction of Hydrolysated Cod By-Products and Sugars'.

Mohan, A, Rajendran, S., He, QS, Bazinet, L \& Udenigwe, CC 2015, Encapsulation of food protein hydrolysates and peptides: a review. RSC Advances, vol. 5, pp. 79270-79278. Mottram, DS 1998, 'Flavour formation in meat and meat products: a review', Food chemistry, vol. 62 , no. 4, pp. 415424.

Morales, FJ, Fernández-Fraguas, C \& Jiménez-Pérez, S 2005, 'Iron-binding ability of melanoidins from food and model systems', Food Chemistry, vol. 90, no. 4, pp. 821-827. 
Nie, X, Xu, D, Zhao, L \& Meng, L 2017, 'Antioxidant Activities of Chicken Bone Peptide Fractions and Their Maillard Reaction Products: Effects of Different Molecular Weight Distributions', Int. J. Food Prop, 20(sup1), pp. S457-S466. Normah, I \& Nashrah, MP 2013, 'Evaluation on the Properties of Mentarang (Pholas orientalis) Protein Hydrolysate', Pertanika Journal of Tropical Agricultural Science, vol. 36, no. 2.

Normah, I \& Noorasma, M 2018, 'Flavour improvement of mud clam (Polymesoda erosa) hydrolysate by using Maillard reaction', International Food Research Journal, vol. 25 , no. 3 .

Ogasawara, M, Katsumata, T \& Egi, M 2006, 'Taste properties of Maillard-reaction products prepared from 1000 to 5000 Da peptide', Food Chemistry, vol. 99, no. 3, pp. 600-604.

O'Mahony, JA, Drapala, KP, Mulcahy, EM \& Mulvihill, DM 2017, 'Controlled glycation of milk proteins and peptides: Functional properties', International Dairy Journal, vol. 67, pp. 16-34.

Qi, JR, Liao, JS, Yin, SW, Zhu, J \& Yang, XQ 2010, 'Formation of acid-precipitated soy protein-dextran conjugates by Maillard reaction in liquid systems', International journal of food science \& technology, vol. 45, no. 12, pp. 2573-2580.

Raksakulthai, R, \& Haard, NF 2003, 'Exopeptidases and their application to reduce bitterness in food: A review', Critical Reviews in Food Science and Nutrition, vol. 43, no. 4, pp. $401 \mathrm{e} 445$.

Rubaie, ZM, Idris, MH, Abu Hena, MK \& King, WS 2012, 'Diversity of cephalopod from selected division of Sarawak, Malaysia; International Journal of Advanced Science, Engineering and Information Technology, vol. 2, no. 4, pp. 8-10.

Shaker, ES, Ghazy, MA \& Shibamoto, T 1995, 'Antioxidative activity of volatile browning reaction products and related compounds in a hexanal/hexanoic acid system', Journal of Agricultural and Food Chemistr, vol. 43, no. 4, pp. 1017-22.

Shahidi, F 1998, Flavour of meat, meat products and seafoods', 2nd ed, London (UK): Blackie Academic \& Professional.

Silva' n, JM, van de Lagemaat, J, Olano, A \& del Castillo, MD, 2006, 'Analysis and biological properties of amino acid derivates formed by Maillard reaction in foods' Journal of Pharmaceutical and Biomedical Analysis, vol. 41, pp. 15431551.

Song, N, Tan, C, Huang, M, Liu, P, Eric, K, Zhang, X, \& Jia, C 2013, 'Transglutaminase crosslinking effect on sensory characteristics and antioxidant activities of Maillard reaction products from soybean protein hydrolysates', Food chemistry, vol. 136, no. 1, pp. 144-151.

Song, R, Shi, QQ, Yang PY \& Wei RB 2017, 'Identification of antibacterial peptides from Maillard reaction products of half-fin anchovy hydrolysates/glucose via LC-ESI-QTOFMS analysis', Journal of Functional Foods, vol. 36, pp. 38795 .

Song, R, Yang PY, Wei, RB \& Ruan, GQ 2016, 'Antioxidative, antibacterial, and food functional properties of the half-fin anchovy hydrolysates-glucose conjugates formed via Maillard reaction', Molecules, vol. 21, no. 6, pp. 795.

Sun, W, Zhao, Q, Zhao, H, Zhao, M \& Yang, B 2010, 'Volatile compounds of Cantonese sausage released at different stages of processing and storage', Food Chemistry, vol. 121, no. 2, pp. 319-325.

Synowiecki, J, Jagietka, R \& Shahidi, F 1996, 'Preparation of hydrolysates from bovine red blood cells and their debittering following plastein reaction', Food Chemistry, vol. 57, pp. 435-439.

Taylor, A \& Linforth, R 2010, Food Flavour Technology, John Wiley \& Sons, Ltd, Publication.

Temussi, PA 2012, 'The good taste of peptides', Journal of Peptide Science, vol. 18, no. 2, pp. 73-82.

Udenigwe, CC \& Rajendran SRCK 2016, Old products, new applications? Considering the multiple bioactivities of plastein in peptide-based functional food design. Current Opinion in Food Science, vol. 8, pp. 8-13.

Van Boekel, MAJS 2006, 'Formation of flavour compounds in the Maillard reaction', Biotechnology Advances, vol. 24, no. 2, pp. 230-233.

Van Lancker, F, Adams, A \& De Kimpe, N 2010, 'Formation of pyrazines in Maillard model systems of lysine-containing dipeptides', Journal of Agricultural and Food Chemistry, vol. 58, no. 4, pp. 2470-2478.

Van Lancker, F, Adams, A \& De Kimpe, N 2011, 'Chemical modifications of peptides and their impact on food properties', Chemical Reviews, vol. 111, no. 12, pp. 78767903.

Van Lancker, F, Adams, A \& De Kimpe, N 2012, 'Impact of the $\mathrm{N}$-terminal amino acid on the formation of pyrazines from peptides in Maillard model systems', Journal of Agricultural and Food Chemistry, vol. 6o, no. 18, pp. 46974708.

Vhangani, LN \& Van Wyk, J 2016, 'Antioxidant activity of Maillard reaction products (MRPs) in a lipid-rich model system', Food Chemistry, vol. 208, no. 301-8. 
Wang, L, Jiang, Z, Tian, B, Bai, LN, Shi, XH \& Zhang, XN 2015, 'Effects of Galactose Concentration on Characteristics of Angiotensin-I-Converting Enzyme Inhibitory Peptides Derived from Bovine Casein in Maillard Reaction', Int. J. Food Prop, vol. 19, no. 10, pp. 2238-2250.

Wu, SP, Hu, J, Wei, LT, Du, LT \& Shi, XW 2014, 'Antioxidant and Antimicrobial Activity of Maillard Reaction Products from Xylan with Chitosan/Chitooligomer/Glucosamine Hydrochloride/Taurine Model Systems', Food Chem, vol. 148, no. 3, pp. 196-203.

Yamabe, N, Kim, YJ, Lee, SY, Cho, EJ, Park, SH, Ham, J, Kim, HY \& Kang, KS 2016, 'Increase in Antioxidant and Anticancer Effects of Ginsenoside Re-Lysine Mixture by Maillard Reaction', Food Chem, vol. 138, pp. 876-883.

Yang, C, Wang, R \& Song, H 2012, 'The mechanism of peptide bonds cleavage and volatile compounds generated from pentapeptide to heptapeptide via Maillard reaction', Food chemistry, vol. 133, no. 2, pp. 373-382.

Yaylayan, VA 2003, 'Recent advances in the chemistry of Strecker degradation and Amadori rearrangement: Implications to aroma and colour formation', Food Science and Technology Research, vol. 9, no. 1, pp. 1-6.

Yilmaz, Y \& Toledo, R 2005, 'Antioxidant activity of watersoluble Maillard reaction products', Food chemistry, vol. 93, no. 2, pp. 273-278.

Yu, M, He, S, Tang, M, Zhang, Z, Zhu, Y \& Sun, H 2018, 'Antioxidant activity and sensory characteristics of Maillard reaction products derived from different peptide fractions of soybean meal hydrolysate', Food Chemistry, vol. 243, pp. 249-257.

Zhang, X, Gao, H, Wang, C, Qayum, A, Mu, Z, Gao, Z \& Jiang, $\mathrm{Z}$ 2018, 'Characterization and comparison of the structure and antioxidant activity of glycosylated whey peptides from two pathways', Food Chemistry, vol. 257, pp. 279-88.

Zhang, D, Ji, W, Peng, Y, Ji, H \& Gao, J 2020, 'Evaluation of Flavour Improvement in Antarctic Krill Defluoridated Hydrolysate by Maillard Reaction Using Sensory Analysis, E-nose, and GC-MS', Journal of Aquatic Food Product Technology, vol. 29, no. 3, pp. 279-292.

Zhang, R, Zhang, BL, He, T, Yi, T, Yang, JP \& He, B 2016, 'Increase of Rutin Antioxidant Activity by Generating Maillard Reaction Products with Lysine', Bioorg. Med. Chem. Lett, vol. 26, pp. 2680-2684.

Zhao, Q, Shen, Q, Guo, R, Wu, J \& Dai, ZY 2016, 'Characterization of flavour properties from fish (Collichthys niveatus) through enzymatic hydrolysis and the maillard reaction', Journal of Aquatic Food Product Technology, vol. 25, no. 4, pp. 482-495. 